|| ISSN(online): 2589-8698 || ISSN(print): 2589-868X || International Journal of Medical and Biomedical Studies

Available Online at www.ijmbs.info

Volume 3, Issue 2; February: 2019; Page No. 57-60

PubMed (National Library of Medicine ID: 101738825)

Index Copernicus Value 2017: 40.03

\title{
A STUDY ON SOCIO-DEMOGRAPHIC DETERMINANTS CAUSING ANEMIA IN ADOLESCENT GIRLS IN THE FIELD PRACTICE AREA OF URBAN HEALTH TRAINING CENTRE, RVRS MEDICAL COLLEGE, BHILWARA.
}

\author{
Mahesh Kumar Choudary ${ }^{1}$, Manmohan Gupta ${ }^{2}$, Rachit Saxena ${ }^{3}$, Sandeep Kumar Uppadhaya ${ }^{4}$ \\ ${ }^{1,3,4}$ Assistant Professor, ${ }^{2}$ Associate Professor \\ 1,2,4 Department of Community Medicine, RVRS Medical College, Bhilwara \\ ${ }^{3}$ Department of Biochemistry, RVRS Medical College, Bhilwara
}

Corresponding Author: Dr. Manmohan Gupta, Associate Professor, Department of Community Medicine, RVRS Medical College, Bhilwara

Article Info: Received 22 January 2019; Accepted 15 February. 2019

Cite this article as: Choudary, M., Gupta, M., Saxena, R., \& Uppadhaya, S. (2019). A STUDY ON SOCIODEMOGRAPHIC DETERMINANTS CAUSING ANEMIA IN ADOLESCENT GIRLS IN THE FIELD PRACTICE AREA OF URBAN HEALTH TRAINING CENTRE, RVRS MEDICAL COLLEGE, BHILWARA. International Journal of Medical and Biomedical Studies, 3(2).

DOI: https://doi.org/10.32553/ijmbs.v3i2.96

Address for Correspondence: Dr. Manmohan Gupta, Associate Professor, Department of Community Medicine, RVRS Medical College, Bhilwara

Conflict of interest: No conflict of interest.

\section{Abstract}

Background: Prevalence of anemia is higher in girls in low socioeconomic status; In addition it gets precipitated by blood loss during menstruation. Anemia in adolescent girls in future attributes to high maternal mortality rate, high incidence of low birth weight babies, high perinatal mortality and fetal wastage.

Methods: This was cross-sectional study. All the adolescent girls studying in standards 9 th $-12^{\text {th }}$ class who were given consent to hemoglobin estimation were included in the study. The girls $\geq 20$ years, and those suffering from any chronic disease were not included in the study. A total of 400 girls were interviewed and were investigated for their Hemoglobin concentration. A predesigned and pretested schedule was used to collect the information about the participants.

Results: Most of the girls i.e.388 (97\%) belonged to the socioeconomic class II, III, IV. The association between SES and anemia was found statistically significant. The association between mother education and anemia was also found statistically significant but association between type of family and anemia was also found statistically Insignificant.

Conclusion: Nutrition education along with nutritional supplementation and iron folic acid tablets should be provided to all girls.

Key Words: Adolescent Girls, Anaemia, Socio-Demographic Characteristics, Education 


\section{Introduction:}

World Health Organization has defined 'adolescence' as a period between 10 and 19 years ${ }^{1}$. Adolescence in girls has been recognized a special period of transition from girlhood to womanhood. Adolescent girls constitute one fifth of the female population in the world.

Overall health status of a person is judged on level of hemoglobin of a person. Prevalence of anemia is higher in girls in low socioeconomic status; In addition it gets precipitated by blood loss during menstruation. Anemia in adolescent girls in future attributes to high maternal mortality rate, high incidence of low birth weight babies, high perinatal mortality and fetal wastage.

In developing countries, girls are most vulnerable group among adolescents. At an early age, they get married and possibility of higher risk of morbidity and mortality gets established at the reproductive age. Health status is the image of increase in physical growth, beginning of the menstruation and rise in fat and muscle mass which meet additional requirement of nutrition among adolescent girls. Physical growth is mainly dependent upon adequate intake of diet which is measured by the food availability in terms of quality, quantity and their ability to ingest, digest and absorb the food ${ }^{2}$.

It is most crucial period for the development of dietary behaviours and later affects the risks of chronic diseases in life. The nutritional status of adolescents mainly depends upon food intake which delivers sufficient energy and other micronutrients for optimal physical, social and cognitive development ${ }^{2}$.
Poor nutritional status during adolescence is an important determinant of health outcomes. Short stature in adolescents resulting from chronic undernutrition is associated with reduced lean body mass and deficiencies in muscular strength and working capacity ${ }^{3}$. So, the present study was carried out to study the prevalence of anaemia and its association with socio-demographic factors among the adolescent girls.

\section{Material and methods}

This was cross-sectional study. All the adolescent girls studying in standards 9 th $-12^{\text {th }}$ class who were given consent to hemoglobin estimation were included in the study. The girls $\geq 20$ years, and those suffering from any chronic disease were not included in the study. A total of 400 girls were interviewed and were investigated for their Hemoglobin concentration. A predesigned and pretested schedule was used to collect the information about the participants.

Haemoglobin was estimated by the Cyanmethaemoglobin method. It is measured in terms of $\mathrm{g} / \mathrm{dl}$. Capillary blood was drawn by finger prick method. Cuvette tube was pre-filled manually with Cyanmethemoglobin reagent. It was incubated for 5 minutes and finally readings were noted. For every sample a blank tube was placed in the machine to avoid the error or check the accuracy.

\section{Results}

The mean age of adolescent girls were $13.2 \pm 2.3$ years and mean $\mathrm{Hb}$ level was $10.1 \pm 2.1 \mathrm{gm} / \mathrm{dl}$.

Table 1: Base line data

\begin{tabular}{|l|l|}
\hline $\mathrm{Hb}$ level $(\mathrm{gm} / \mathrm{dl})$ & $10.1 \pm 2.1 \mathrm{gm} / \mathrm{dl}$ \\
\hline Age (years) & $13.2 \pm 2.3$ years \\
\hline
\end{tabular}




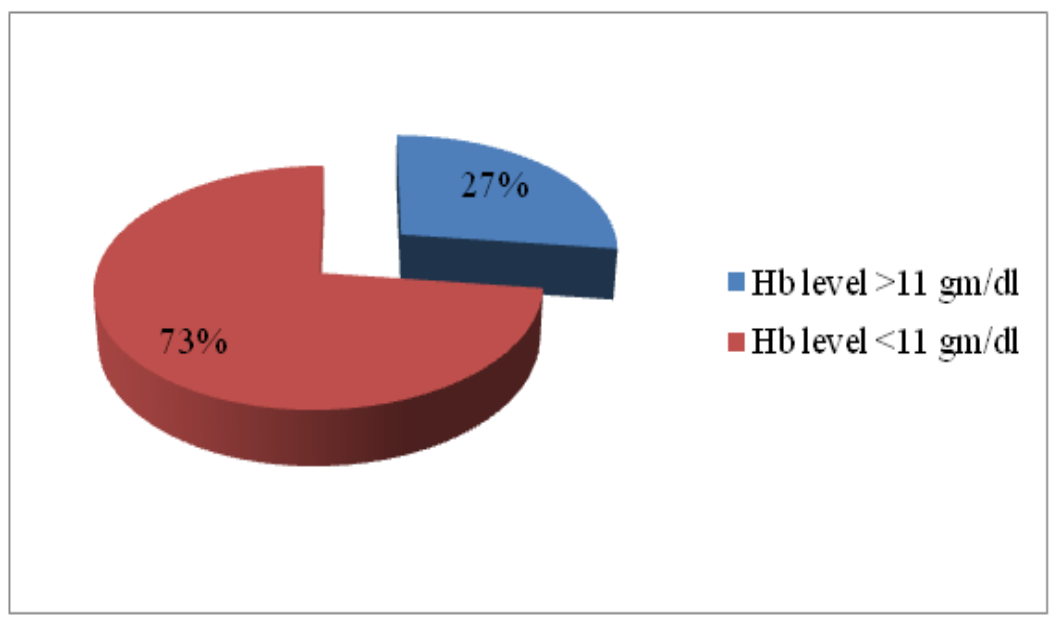

Table 2: Association between socio-demographic profile and anemia

\begin{tabular}{|l|l|l|l|}
\hline $\begin{array}{l}\text { Socio-demographic } \\
\text { variable }\end{array}$ & $\begin{array}{l}\text { Anemia present } \\
(\mathrm{n}=292)\end{array}$ & $\begin{array}{l}\text { Anemia absent } \\
(\mathrm{n}=108)\end{array}$ & Statistics \\
\hline $\begin{array}{l}\text { Socio-demographic } \\
\text { class }\end{array}$ & & & \\
\hline I & 4 & 8 & P-Value $=0.000$ \\
\hline II & 16 & 32 & \\
\hline III & 40 & 48 & \\
\hline IV & 232 & 20 & P-Value $=0.141$ \\
\hline Type of family & & & \\
\hline Joint & 64 & 32 & P-Value $=0.000$ \\
\hline Nuclear & 228 & 76 & \\
\hline Mother education & & & \\
\hline Illiterate & 72 & 4 & \\
\hline Primary & 88 & 12 & \\
\hline Secondary & 52 & 16 & \\
\hline Graduate & 100 & 76 & \\
\hline
\end{tabular}

Most of the girls i.e.388 (97\%) belonged to the socioeconomic class II, III, IV. The association between SES and anemia was found statistically significant. The association between mother education and anemia was also found statistically significant but association between type of family and anemia was also found statistically Insignificant.

\section{Discussion}

The National Pilot Programme on Control of Micronutrient Malnutriton launched in 1995 by the Ministry of Health and Family Welfare $(2000)^{4}$ reported point prevalence of anaemia in various age groups and found to be high in both sexes. In adolescents, the prevalence rate of mild and moderate anaemia was also very-very high i.e., 65.8 per cent in boys and 81.3 per cent in girls with severe anaemia of boys 3.8 per cent and girls $6.0 \%$.

In the present study, the overall prevalence of anaemia was 73.00 per cent in adolescent girls, which is higher than the prevalence (34.5\%) reported by Rawat et al $(2000)^{5}$ among adolescent girls in rural area of Meerut. But it is reported to be low as compared to 73.7 per cent reported by Misra et $\mathrm{al}^{6}$ and multicentric study in 3 regions of India (Mumbai, Gujarat and Delhi) ${ }^{7}$ which showed anaemia prevalence as 62-65 per 
cent, 57-65 per cent and 48-50 per cent respectively in adolescent girls.

Reverse association was seen between socioeconomic status and prevalence of anaemia in adolescent girls; lower the socio-economic status, and higher the prevalence of anaemia in our study. Thavraj and Reddy $(1985)^{8}$ noted iron deficiency among 20 per cent of healthy nonanaemic high income group children. Hence it is evident that a significant proportion of the apparently healthy children belonging to the higher socio-economic class suffers from overt anaemia and may have latent iron deficiency anaemia if not anaemic. The possible reason for this could be the poor bio-availability of iron in Indian diet. Kapoor and Aneja $(1991)^{9}$ noted prevalence of anaemia in 47 per cent of adolescent girls belonging to high socioeconomic group and 56 per cent in lower middle class. In a study by Vasanthi et al $(1994)^{10}$, it was found that mean $\mathrm{Hb}$ showed a rising trend with improved socioeconomic status and most of the children belonging to lower socio-economic status were anaemic. This may be because of better availability of high quality of food for children with better socio-economic status.

The association between mother education and anemia was also found statistically significant in our study. Rawat et al ${ }^{5}$ also reported that the prevalence of anaemia was more in adolescent girls who are illiterate $(42.2 \%)$ and just literate (40.3\%) mothers as compared to educated mothers. It shows a significant correlation between the level of parental education and girl's education. Particularly, the education of mothers is a significant factor for girl's education.

\section{Conclusion}

Nutrition education along with nutritional supplementation and iron folic acid tablets should be provided to all girls.

\section{References}

1. Programming for adolescent health and development: WHO Tech.Rep.Sr.no 886; 1996.

2. Lwanga SK, Lemeshaw S. Sample size determination in health, a practical manual: WHO; 1991.

3. Nutritional anemia: WHO Scientific Group. Tech.Rep.Ser. No 405; 1968. 5-15.

4. Control of Nutritional Anemia with special Reference to Iron Deficiency: WHO Tech.Rep.Ser.No 580; 1975.

5. Rawat C.M.S. (2000): An Epidemiological Study of Anaemia in Adolescent Girls in the Rural Area of Meerut. (Thesis submitted for M.D. in Community Medicine, C.C.S. University, Meerut).

6. Misra et al: Study of Physical Growth, Anaemia and Reproductive Health Status of Adolescent Girls in Urban Poor (Delhi) published by MAMTA Health Institute for Mother and Child.

7. IDA Control - A Public Health Programme Priority (1998) Shiela C Vir, UNICEF, Proc, Nutri. Soc. India Vol 47 : 45-73.

8. Thavraj V.K. and Reddy V. (1985) Serum Ferritin in Healthy School Children. Indian Paed, 22:51-52.

9. Kapoor G. and Aneja S. (1992) Nutritional Discorders in Adolescent Girls, Indian Paed. 29: 969-973.

10. Vasanthi Cr. Pawashe, A.B. Susie H, Sujatha T. and Ramesh L. (1994) Nutritional Status of Adolescent Girls from Rural and Urban Slums. Indian Paed (31):127-132. 